Watanabe, T. \& Watanabe, M. (1959). J. gen. Microbiol. 21, 16-29

\title{
Transduction of Streptomycin Resistance in Salmonella typhimurium
}

\author{
By T. WATANABE* AND M. WATANABE \\ Department of Zoology, Columbia University, New York 27, N.Y., U.S.A.
}

SUMMARY: In contrast to the failure of several previous workers to transduce streptomycin resistance, it was found that streptomycin indifference (one-step complete resistance) could quite reproducibly be transduced. For the expression of indifference after transduction, the infected bacteria must be allowed to divide at least once. This finding is assumed to reflect a segregation delay because of the recessive nature of the indifference locus. But from the fact that transduced indifference is phenotypically expressed from partial to complete resistance, the participation of a phenomic lag is also assumed.

In addition to the delay of phenotypic expression, several other aspects of transduction of indifference were studied and a close similarity of the behaviour of indifference to other chromosomal markers was found.

The transduction of one-step intermediate resistance into sensitive and into other one-step intermediate resistant recipients, however, was found to be difficult to demonstrate if it occurs at all. The difficulty of detecting resistant transductants is apparently not due to the killing of resistant bacteria in the presence of sensitive cells.

The difficulty of transducing intermediate resistance is assumed to be due to a selective disadvantage of the resistant, slow-growing transductants. The failure to find transductions even with slow-growing sensitive recipients may have been due to the fact that successful transductions yielded even slower growing resistant clones.

On the other hand, the transduction of second-step resistance into one-step resistant mutants was found to take place and the transduction of indifference into one-step resistant bacteria yielded slow-growing indifferent transductants.

Cavalli (1952) discovered multiple loci for chloramphenicol and terramycin resistance by the use of recombination in Escherichia coli, strain K-12; on the other hand, Demerec (1950) and Newcombe \& Nyholm (1950) reported that streptomycin resistance is controlled by a single locus or by very closely linked loci in the same bacterial strain. We have reported that in streptomycin resistance the complete resistance which is developed in a single step with low mutation rates is different in various aspects from the multiple-step resistance, and we have given the name of streptomycin indifference to one-step complete resistance (Watanabe, 1954; Watanabe, Fukasawa \& Ushiba, 1957). The genetics of the apparently one-step complete resistance has been studied by many workers, but much attention has not been paid to multiple-step resistance, although Hotchkiss (1951) clarified the multiple-step nature of penicillin resistance and reported that streptomycin resistance is developed in both single and multiple steps as revealed by transformation studies in Diplococcus pneumoniae (Hotchkiss, 1952).

* Present address: Department of Bacteriology, Keio University School of Medicine, Tokyo, Japan. 
Since transduction was discovered by Zinder \& Lederberg (1952), and it was reported that streptomycin resistance is transducible, transduction has been thought to be an excellent technique for the study of the genetics of drug resistance. However, several workers (see Bryson \& Szybalski, 1955; and Bryson \& Demerec, 1955), including Zinder himself (personal communication), have been unable to reproduce their transduction experiments on resistance to streptomycin as well as to other drugs in Salmonella typhimurium strain LT-2 which was originally used by Zinder and Lederberg. There are some workers who reported that streptomycin resistance is transducible (in Salmonella typhosa, Baron, 1953; in $S$. anatum, Iseki \& Sakai, 1954; in S. typhimurium, Shimizu, 1955; in Escherichia coli, Lennox, 1955), but it is not clear which type of streptomycin resistance is involved in their studies. We believe that it is important to identify the type of streptomycin resistance whenever we deal with it, because, as will be reported in this paper, streptomycin resistance involves multiple loci, and not only are their phenotypes apparently different from one another but it is also likely that the biochemical mechanisms of resistance controlled by these loci are different.

In the first part of this paper we will report on the transduction of streptomycin indifference, about which much data have been already accumulated by other genetic methods and which is obviously controlled by a single locus or by very closely linked loci. In the following part, studies on the transduction of multiple-step resistance into sensitive or resistant bacteria will be reported.

\section{METHODS}

\section{Strains and media}

Throughout the present studies, Salmonella typhimurium, strains LT-2 and LT-7, and temperate phage PLT-22 were used. Both of the bacterial strains were found to show rather high resistance to streptomycin on ordinary nutrient media and, because this high resistance has made the fine analysis of stepwise increase or decrease of streptomycin resistance difficult, it was decided to use low phosphate medium. It has already been established that phosphate reverses the action of streptomycin (Watanabe, 1954; Hurwitz \& Rosano, 1958). The low phosphate medium had the following \% composition: $\mathrm{NH}_{4} \mathrm{Cl}$ $0.05, \mathrm{NH}_{4} \mathrm{NO}_{3} 0.01, \mathrm{Na}_{2} \mathrm{SO}_{4} 0.02, \mathrm{~K}_{2} \mathrm{HPO}_{4} 0.03, \mathrm{KH}_{2} \mathrm{PO}_{4} \mathrm{0} \cdot 01, \mathrm{MgSO}_{4} \mathrm{0} 01$, $\mathrm{CaCl}_{2} \mathbf{0} \cdot 001$, yeast extract (Difco) $0 \cdot 5$, NZ-case (Sheffield) $0 \cdot 5$, (agar 1.5).

\section{Isolation of mutants}

The streptomycin indifferent mutants were obtained by exposing a large number of wild-type bacteria to more than $500 \mu \mathrm{g}$. of streptomycin sulphate per $\mathrm{ml}$. In lower concentrations of the antibiotic, intermediate resistant mutants were selected as well. After repeated single colony isolations, the indifferent bacteria were grown in liquid medium with aeration and during logarithmic growth they were infected with phage grown on wild-type bacteria with a multiplicity of input of about $10^{-3}$. This low multiplicity was chosen in order to let all the phage particles multiply on the mutant bacteria. The 
infected bacteria were further aerated at $37^{\circ}$, and after $5 \mathrm{hr}$. the culture was centrifuged and the supernatant treated with chloroform. Phage titrations were carried out by the method of Adams (1950).

For isolating intermediate streptomycin resistant mutants independently, overnight cultures in $1 \mathrm{ml}$. of liquid medium were obtained starting from about 100 cells in each culture. One-tenth ml. of each culture was plated on agar medium containing 25, 50, 100 and $250 \mu \mathrm{g}$. streptomycin $/ \mathrm{ml}$. and after 5 days' incubation colonies were picked at random, re-isolated on to streptomycin-free agar plates, and used as first-step mutants, although some of them might be multiple-step mutants. When two-step mutants were required, firststep mutants were plated on agar medium containing higher concentrations of streptomycin and the colonies developing used as two-step mutants.

\section{Preparation of transducing phage}

As reported previously (Watanabe, 1954), most of the intermediate resistant mutants are genetically unstable slow growers; fast-growing mutants arise which are less resistant to streptomycin than the original slow-growing resistant mutants. Therefore, in order to maintain the homogeneity of a population of intermediate resistant mutants the bacteria had to be subcultured on agar and fast-growing mutant colonies had to be avoided. Also when phage were to be produced on them, the slow-growing resistant cells were grown on agar plates and only the small colonies were scraped off, avoiding the areas including the large colonies. The harvested bacteria were suspended in liquid medium, infected with phage at a low multiplicity of input $\left(10^{-3}\right)$ and aerated for $5 \mathrm{hr}$. In some of the bacterial inocula thus prepared, and also in the infected cultures thus grown, fast-growing mutants could spontaneously arise, but the presence of phage particles which carry the genome of fast-growing mutants was easily detected by infecting the original slow-growing mutants with phage stocks thus obtained and by observing if fast-growing transductants appeared. The phage stocks which contained phage particles carrying the genome of fast-growing mutants were discarded and good stocks were prepared.

It is also possible that sometimes the recipient bacteria, which were prepared by scraping off only the small colonies and suspending them in liquid medium, could contain fast-growing mutants. This possibility was checked by plating the recipient bacterial suspension on streptomycin-free agar to see if any fastgrowing colonies arose. These suspensions which gave fast-growing mutant colonies on the control plates were discarded and the preparation of recipient bacteria was repeated. Even in repeated experiments some of the slow-growing resistant mutants were found to be so unstable that their transduction analysis was found to be impossible.

\section{Transduction}

In transduction of indifference or intermediate resistance into sensitive bacteria the recipient sensitive bacteria were infected with the donor phage from indifferent or intermediate resistant mutants by mixing equal volumes of bacteria and phage. As will be mentioned below, when the infected bacteria 
were immediately exposed to streptomycin, no transductants were recovered, showing that there is a delay for phenotypic expression in the transduction of indifference and intermediate resistance. Therefore, the following methods were used to allow the transductants to express their phenotype: the first is the delayed selection technique (Newcombe, 1952), the second being the replica plating (Lederberg \& Lederberg, 1952) and the third the ordinary liquid culture method.

Delayed selection technique. $1 \mathrm{ml}$. of the infected bacteria was mixed with $9 \mathrm{ml}$. of melted agar medium in plates which were then incubated for varying periods of time after which $10 \mathrm{ml}$. of melted agar medium containing varying concentrations of streptomycin was layered on top. The plates were then kept in a refrigerator overnight to allow the streptomycin to diffuse into the lowe1 layer. Then they were incubated at $37^{\circ}$ for 5 days before the developed colonies were scored.

Replica plating technique. The infected bacteria were spread on the surface of agar plates, grown for varying periods of time and then replicated with velveteen pads on agar plates containing varying concentrations of streptomycin.

Liquid culture method. The infected bacteria were grown with aeration in liquid medium from which aliquots were withdrawn at various times and plated on agar containing varying concentrations of streptomycin. In contrast to the above methods, it is naturally difficult with this method to determine accurately the numbers of transductant clones, because the transductants grow mixed together with the non-transductants. In some experiments the culture of infected bacteria was allowed to undergo more divisions by diluting the culture with fresh liquid medium after it had reached saturation.

The transduction of first-step resistance into sensitive bacteria was found to be difficult, and the reason for this difficulty was assumed to be a selective disadvantage of the resistant transductants compared to wild-type recipient bacteria because of differences in their growth rates. Therefore, a slow-growing mutant, which was obtained by growing wild-type bacteria in liquid medium containing more than $\mathrm{M} / 1000 \mathrm{BaCl}_{2}$ and which was sensitive to streptomycin, was also used as a recipient.

\section{RESULTS}

\section{Characteristics of indifferent mutants from LT-2 and LT-7}

As previously reported (Watanabe, 1954), the indifferent mutants of Salmonella enteritidis, strain no. 11, and Escherichia coli, strains K-12 and B-19, show generation times approximately equal to their wild-types and complete resistance to streptomycin. In LT-2 and LT-7 colonies of indifferent mutants, developed on the selective agar media containing more than $500 \mu \mathrm{g}$. of streptomycin per ml., were mostly composed of cells that grew rapidly when they were re-isolated on agar without streptomycin, but some were composed of fast-growing and slow-growing cells. It is not easy, however, to decide which of these two types is the primary mutant. It was found that when fastgrowing mutants were grown on agar with high concentrations of streptomycin, papillae developed from which slow-growing indifferent mutants were 
isolated. When the slow-growing indifferent mutants were grown in the absence of streptomycin, fast-growing sectors developed from which fastgrowing indifferent mutants were isolated. It seems that in the presence of high concentrations of streptomycin the slow-growing type has a selective advantage, while the situation is reversed in the absence of the antibiotic.

When phage was to be grown on a slow-growing type, the bacteria were grown on agar plates, scraped off with a loop (avoiding the areas which contained large colonies), suspended in liquid medium and then infected with phage.

\section{Transduction of fast-growing indifference}

(1) Detection of transductants with the delayed selection technique. As shown in Table 1, there were no indifferent transductants recovered when the infected bacteria were not allowed to divide before they were exposed to streptomycin. After $3 \mathrm{hr}$. of growth the number of visible transductant colonies decreased

Table 1. Detection of streptomycin indifferent transductants of Salmonella typhimurium, strains LT-2 and LT-7, with the delayed selection technique

\begin{tabular}{|c|c|c|c|c|c|c|}
\hline \multirow[b]{2}{*}{ Recipient } & \multirow[b]{2}{*}{ Donor } & \multicolumn{5}{|c|}{$\begin{array}{c}\text { Count of transductants after } \\
\text { pre-incubation for* }\end{array}$} \\
\hline & & $0 \mathrm{hr}$. & $1 \mathrm{hr}$. & $2 \mathrm{hr}$. & $\mathbf{3}$ hr. & $4 \mathrm{hr}$. \\
\hline \multicolumn{7}{|l|}{ Experiment 1} \\
\hline $\begin{array}{l}\text { LT-2 wild-type } \\
\text { bacteria }\end{array}$ & $\begin{array}{l}\text { Phage from LT-2 wild- } \\
\text { type bacteria }\end{array}$ & $\mathbf{0}$ & $\mathbf{0}$ & 0 & 0 & $\mathbf{0}$ \\
\hline $\begin{array}{l}\text { LT-2 wild-type } \\
\text { bacteria }\end{array}$ & $\begin{array}{l}\text { Phage from LT-2 in- } \\
\text { different mutant }\end{array}$ & 0 & 746 & $\dagger$ & $\dagger$ & $\dagger$ \\
\hline $\begin{array}{l}\text { LT-7 wild-type } \\
\text { bacteria }\end{array}$ & $\begin{array}{l}\text { Phage from LT-7 wild- } \\
\text { type bacteria }\end{array}$ & $\mathbf{0}$ & $\mathbf{0}$ & $\mathbf{0}$ & $\mathbf{0}$ & $\mathbf{0}$ \\
\hline $\begin{array}{l}\text { LT-7 wild-type } \\
\text { bacteria }\end{array}$ & $\begin{array}{l}\text { Phage from LT-7 in- } \\
\text { different mutant }\end{array}$ & 0 & 239 & $\dagger$ & $\dagger$ & $\dagger$ \\
\hline \multicolumn{7}{|l|}{ Experiment 2} \\
\hline $\begin{array}{l}\text { LT-2 wild-type } \\
\text { bacteria }\end{array}$ & $\begin{array}{l}\text { Phage from LT-2 wild- } \\
\text { type bacteria }\end{array}$ & $\mathbf{0}$ & $\mathbf{0}$ & $\mathbf{0}$ & 0 & $\mathbf{0}$ \\
\hline $\begin{array}{l}\text { LT-2 wild-type } \\
\text { bacteria }\end{array}$ & $\begin{array}{l}\text { Phage from LT-2 in- } \\
\text { different mutant }\end{array}$ & 0 & 53 & 85 & 82 & $\dagger$ \\
\hline $\begin{array}{l}\text { LT-7 wild-type } \\
\text { bacteria }\end{array}$ & $\begin{array}{l}\text { Phage from LT-7 wild- } \\
\text { type bacteria }\end{array}$ & 0 & $\mathbf{0}$ & $\mathbf{0}$ & $\mathbf{0}$ & $\mathbf{0}$ \\
\hline $\begin{array}{l}\text { LT-7 wild-type } \\
\text { bacteria }\end{array}$ & $\begin{array}{l}\text { Phage from LT-7 in- } \\
\text { different mutant }\end{array}$ & $\mathbf{0}$ & 19 & 28 & 17 & $\dagger$ \\
\hline
\end{tabular}

* Pre-incubation means the incubation of the phage-infected bacteria in the streptomycinfree agar layer before streptomycin agar $(1000 \mu \mathrm{g} . / \mathrm{ml}$.) is added to the top.

$\dagger$ After $4 \mathrm{hr}$. pre-incubation, the background growth became too dense to allow visible indifferent colonies to form.

considerably and finally none could be detected, because the background growth became too heavy to allow the transductant colonies to be detected. Therefore, this method does not seem to be a good one for studying the kinetics of the phenotypic expression of transductants.

(2) Detection of transductants with the replica-plating technique. With this technique, it was shown again that there exists a delay in the phenotypic expression of indifferent transductants. It is probable, however, that all of the 
transductant clones were not successfully replicated by this technique, because, unless the master plates were spread with so many bacteria that all of the colonies could not be successfully replicated, transductant clones were too few to be detected. Accordingly, this method is also not ideal for studying the kinetics of transduction of indifference.

(3) Detection of transductants with the liquid culture method. As pointed out in Methods, it is difficult to observe the individual clones of transductants with this method, but because the generation time of the indifferent transductants is fortunately about equal to that of the wild-type, the analysis of the delay of phenotypic expression of indifference seems rather easy with this method. As shown in Table 2, the frequency of indifferent transductants reaches its maximum after several generations, the minimum requirement for phenotypic

Table 2. Detection of streptomycin indifferent transductants of Salmonella typhimurium, strain LT-2, with the liquid-culture method

\begin{tabular}{|c|c|c|c|c|c|}
\hline $\begin{array}{l}\text { Duration } \\
\text { of } \\
\text { incubation } \\
(\mathrm{hr} .)\end{array}$ & Donor phage from & $\begin{array}{c}\text { Viable } \\
\text { bacteria } \\
\text { per ml. }\end{array}$ & $\begin{array}{l}\text { Indifferent } \\
\text { bacteria } \\
\text { per ml.* }\end{array}$ & $\begin{array}{c}\text { Frequency } \\
\text { of } \\
\text { transductants }\end{array}$ & $\begin{array}{l}\text { Factor o } \\
\text { increase } \\
\text { of viabl } \\
\text { bacterie }\end{array}$ \\
\hline $\mathbf{0}$ & $\begin{array}{l}\text { No phage } \\
\text { Wild-type bacteria } \\
\text { Indifferent mutant }\end{array}$ & $\begin{array}{l}3.4 \times 10^{8} \\
2 \cdot 4 \times 10^{8} \\
2 \cdot 5 \times 10^{8}\end{array}$ & $\begin{array}{l}\mathbf{0} \\
\mathbf{0} \\
\mathbf{0}\end{array}$ & $\begin{array}{l}0 / 3.4 \times 10^{8} \\
0 / 2.4 \times 10^{8} \\
0 / 2.5 \times 10^{8}\end{array}$ & $\begin{array}{l}1 \cdot 0 \\
1 \cdot 0 \\
1 \cdot 0\end{array}$ \\
\hline 1 & $\begin{array}{l}\text { No phage } \\
\text { Wild-type bacteria } \\
\text { Indifferent mutant }\end{array}$ & $\begin{array}{l}6.0 \times 10^{8} \\
3.9 \times 10^{8} \\
3.5 \times 10^{8}\end{array}$ & $\begin{array}{l}\mathbf{0} \\
0 \\
\mathbf{1}\end{array}$ & $\begin{array}{l}0 / 6.0 \times 10^{8} \\
0 / 3.9 \times 10^{8} \\
1 / 3.5 \times 10^{8}\end{array}$ & $\begin{array}{l}1 \cdot 8 \\
1 \cdot 6 \\
1 \cdot 4\end{array}$ \\
\hline 2 & $\begin{array}{l}\text { No phage } \\
\text { Wild-type bacteria } \\
\text { Indifferent mutant }\end{array}$ & $\begin{array}{l}1.3 \times 10^{9} \\
7 \cdot 6 \times 10^{8} \\
7 \cdot 7 \times 10^{8}\end{array}$ & $\begin{array}{r}0 \\
0 \\
129\end{array}$ & $\begin{array}{l}0 / 1.3 \times 10^{9} \\
0 / 7 \cdot 6 \times 10^{8} \\
1 / 5.9 \times 10^{6}\end{array}$ & $\begin{array}{l}3 \cdot 8 \\
3 \cdot 2 \\
3 \cdot 1\end{array}$ \\
\hline 3 & $\begin{array}{l}\text { No phage } \\
\text { Wild-type bacteria } \\
\text { Indifferent mutant }\end{array}$ & $\begin{array}{l}1.6 \times 10^{9} \\
8.0 \times 10^{8} \\
1.0 \times 10^{9}\end{array}$ & $\begin{array}{r}0 \\
0 \\
275\end{array}$ & $\begin{array}{l}0 / 1.6 \times 10^{8} \\
0 / 8.0 \times 10^{8} \\
1 / 3.5 \times 10^{6}\end{array}$ & $\begin{array}{l}4 \cdot 7 \\
3 \cdot 3 \\
4 \cdot 0\end{array}$ \\
\hline 4 & $\begin{array}{l}\text { No phage } \\
\text { Wild-type bacteria } \\
\text { Indifferent mutant }\end{array}$ & $\begin{array}{l}2 \cdot 1 \times 10^{9} \\
1 \cdot 0 \times 10^{9} \\
1 \cdot 1 \times 10^{9}\end{array}$ & $\begin{array}{r}0 \\
0 \\
663\end{array}$ & $\begin{array}{l}0 / 2 \cdot 1 \times 10^{9} \\
0 / 1.0 \times 10^{9} \\
1 / 1.6 \times 10^{6}\end{array}$ & $\begin{array}{l}6 \cdot 2 \\
4 \cdot 1 \\
4 \cdot 0\end{array}$ \\
\hline 5 & $\begin{array}{l}\text { No phage } \\
\text { Wild-type bacteria } \\
\text { Indifferent mutant }\end{array}$ & $\begin{array}{l}2.4 \times 10^{9} \\
1.4 \times 10^{9} \\
1.4 \times 10^{9}\end{array}$ & $\begin{array}{r}0 \\
0 \\
1280\end{array}$ & $\begin{array}{l}0 / 2 \cdot 4 \times 10^{9} \\
0 / 1 \cdot 4 \times 10^{9} \\
1 / 1 \cdot 1 \times 10^{6}\end{array}$ & $\begin{array}{l}7 \cdot 1 \\
5 \cdot 8 \\
5 \cdot 6\end{array}$ \\
\hline 7 & $\begin{array}{l}\text { No phage } \\
\text { Wild-type bacteria } \\
\text { Indifferent mutant }\end{array}$ & $\begin{array}{l}2.8 \times 10^{9} \\
1.8 \times 10^{9} \\
1.8 \times 10^{9}\end{array}$ & $\begin{array}{r}0 \\
0 \\
3990\end{array}$ & $\begin{array}{l}0 / 2.8 \times 10^{9} \\
0 / 1.8 \times 10^{9} \\
1 / 4.5 \times 10^{5}\end{array}$ & $\begin{array}{l}8 \cdot 2 \\
7 \cdot 5 \\
7 \cdot 2\end{array}$ \\
\hline 16 & $\begin{array}{l}\text { No phage } \\
\text { Wild-type bacteria } \\
\text { Indifferent mutant }\end{array}$ & $\frac{t}{7.6 \times 10^{8}}$ & $\frac{-}{3220}$ & $\frac{-}{1 / 2 \cdot 4 \times 10^{5}}$ & $\overline{3 \cdot 0}$ \\
\hline
\end{tabular}

* Streptomycin indifferent cells were scored on agar plates containing $500 \mu \mathrm{g}$. of streptomycin per ml.

+ Not tested.

expression being about one division. With this method, it is not possible to determine the numbers of divisions accurately and also there is a possibility that phage infection may take place at different times among the many recipient bacteria. 
Lederberg (1951) reported that streptomycin resistance in Escherichia coli, strain K-12, is recessive to sensitivity and it is assumed to be true also in the case of Salmonella typhimurium, despite the contrary finding of Hotchkiss in Diplococcus pneumoniae (1957). However, when indifferent transductants were detected on varying concentrations of streptomycin, more transductants were recovered earlier on lower drug concentrations (Table 3), suggesting that the phenotypic expression of transduction of indifference takes place gradually from partial to complete resistance. This finding is comparable to the observation of a similar phenomenon in the transformation of streptomycin resistance in Haemophilus influenzae (Alexander \& Leidy, 1953), and seems to suggest the participation of phenomic lag in the delay of phenotypic expression.

Table 3. Detection of streptomycin indifferent transductants of Salmonella typhimurium, strain LT-2, by plating from liquid cultures on to varying concentrations of streptomycin

\begin{tabular}{|c|c|c|c|c|c|c|c|}
\hline \multirow{2}{*}{$\begin{array}{l}\text { Multiplicity } \\
\text { of input }\end{array}$} & \multirow{2}{*}{$\begin{array}{l}\text { Duration of } \\
\text { incubation } \\
\quad(\mathrm{hr} .)\end{array}$} & \multicolumn{6}{|c|}{$\begin{array}{l}\text { Indifferent transductant colonies developed } \\
\text { on agar plates containing the following concentrations } \\
\text { of streptomycin }(\mu \mathrm{g} . / \mathrm{ml} .)\end{array}$} \\
\hline & & 100 & 250 & 500 & 1000 & 5000 & 10,000 \\
\hline \multirow[t]{7}{*}{30} & 0 & 0 & 0 & 0 & 0 & 0 & 0 \\
\hline & 1 & 0 & 0 & 0 & 0 & 0 & 0 \\
\hline & 2 & 8 & $\mathbf{3}$ & 1 & 0 & 0 & 0 \\
\hline & 3 & 63 & 26 & $\mathbf{5}$ & 4 & 0 & 0 \\
\hline & 4 & 346 & 259 & 128 & 48 & 0 & o \\
\hline & 5 & 69 & 61 & 62 & 51 & 39 & 49 \\
\hline & 7 & 336 & 335 & 301 & 351 & 71 & 78 \\
\hline \multirow[t]{6}{*}{0.5} & 0 & 0 & 0 & $\mathbf{0}$ & 0 & 0 & 0 \\
\hline & 1 & 0 & 0 & 0 & 0 & 0 & 0 \\
\hline & 2 & 0 & 0 & 0 & 0 & o & 0 \\
\hline & 3 & 10 & 9 & 3 & o & 0 & $\mathbf{0}$ \\
\hline & 4 & 19 & 16 & 11 & 7 & 0 & o \\
\hline & 6 & 6 & 7 & 11 & 10 & $\mathbf{3}$ & 3 \\
\hline
\end{tabular}

$3.4 \times 10^{8} / \mathrm{ml}$. of wild-type bacteria were infected with phage from an indifferent mutant with the above multiplicities of input and aerated for varying durations after which $0 \cdot 1 \mathrm{ml}$. of the undiluted culture was plated on each streptomycin agar plate.

After $4 \mathrm{hr}$. aeration of the culture, they were diluted 10 times with fresh liquid medium to allow the bacteria to continue dividing.

Essentially similar results were obtained also when donor phage was grown on slow-growing indifferent mutants, and the indifferent transductants obtained in this case were found to be all fast growing. These results seem to suggest that the slow growth of the slow-growing indifferent mutants is brought about by a secondary mutation at a locus other than the indifference locus. The experiments described below were carried out exclusively with fastgrowing indifferent mutants as donors. 


\section{Other conditions of transduction of indifference}

As described above, the delay in phenotypic expression is important in the transduction of indifference: besides this there are several conditions which may alter the efficiency of transduction.

(1) Transduction with varying multiplicities of input. When the number of recipient bacteria was kept constant and the titres of the donor phage were varied so as to give varying multiplicities of input, higher frequencies of transduction were obtained in higher multiplicities.

(2) Transduction with varying numbers of recipient bacteria and a constant titre of donor phage. When the titre of the donor phage was kept constant and the number of recipient bacteria was varied, it was found that the titres of the donor phage rather than the numbers of recipient bacteria determine the frequencies of transduction.

These results are comparable to those obtained by Zinder \& Lederberg (1952) in the transduction of prototrophy and confirm the reasonableness of the notion of transduction per phage (Zinder, 1955).

(3) Transduction of recipient bacteria lysogenized with homologous phage. Wild-type bacteria were exposed to a high titre of PLT-22 phage and the survivors were repeatedly isolated on agar medium to get rid of carried-over phage. The lysogeny of the strain was proved by its immunity to a virulent mutant H-5 (obtained from Dr M. Demerec) of PLT-22 phage, the spontaneous release of the phage and ultraviolet induction of the phage. When thelysogenized bacteria were used as recipients, transduction efficiency was much lower than with the non-lysogenic recipients. Also with the virulent mutant $\mathbf{H}-5$ as a donor phage, transduction with low frequency was observed in lysogenic recipient bacteria. These findings are identical to those reported by Zinder (1955) on other markers.

(4) Cross-transduction between LT-2 and LT-7. When the phages grown on the streptomycin indifferent mutants of LT-2 and LT-7 were used as donors and the wild-type bacteria of LT-2 and LT-7 were used as recipients, the efficiencies of transduction were about equal in the cross-transductions.

(5) Abortive transduction. On streptomycin agar, small colonies such as were found by Ozeki in the abortive transduction of prototrophy were looked for but none was found. This failure is not surprising, because, as mentioned above, streptomycin indifference is possibly recessive to sensitivity, and furthermore the transduction of streptomycin indifference requires a delay for its phenotypic expression. The colonies developed on streptomycin agar were found to be composed of exclusively indifferent cells.

\section{Transduction of one-step intermediate resistance into sensitive bacteria}

Phage was grown on one-step intermediate resistant mutants and sensitive recipient bacteria were infected with this phage. The above-mentioned three methods were employed to allow the possible transductants to express their phenotype but none of these methods gave significant results, because the numbers of the resistant colonies developed did not differ significantly whether 
phage grown on wild-type or resistant bacteria was used to infect the recipient strain.

Under this circumstance two possibilities which would interfere with the detection of transductants were investigated. One of them was the phenomenon of 'co-killing' discovered by Saz \& Eagle (1953) for penicillin. Here penicillin-resistant cells are killed by penicillin when they are kept together with penicillin-sensitive cells. It was thought possible that the resistant transductants in streptomycin may be killed by subinhibitory concentrations of the antibiotic and escape detection, because they are plated with a large number of sensitive non-transductants. This possibility was examined by a reconstruction experiment, but detectable co-killing by streptomycin was not found.

The second possibility which could interfere with the detection of resistant transductants was that the resistant transductants may be selected against because of their slow growth compared to the fast growth of the sensitive non-transductants. For studying this possibility, a slow-growing mutant was obtained by growing wild-type bacteria in liquid medium containing more than $\mathrm{M} / 1000 \mathrm{BaCl}_{2}$ (Watanabe, 1954). The mutant was found to be as sensitive as the wild-type to streptomycin by determining their survival curves against streptomycin. The transduction experiments in which this slow-growing mutant was used as a recipient again failed to show significant transduction. By comparing their colony sizes on agar medium this slow-growing mutant was found to become even slower growing when it became streptomycin resistant.

Transduction of second-step resistance into one-step resistant bacteria

When about $10^{8}$ cells of a one-step resistant mutant which has the average resistance of $100 \mu \mathrm{g} . / \mathrm{ml}$. were plated on agar medium containing varying concentrations of streptomycin, 5 colonies developed on agar containing $1000 \mu \mathrm{g}$. of streptomycin per ml. One of them was used as a two-step resistant mutant. A transduction experiment was performed by using this one-step resistant mutant as a recipient and the two-step resistant mutant as a donor. The detection of two-step transductants was done with the liquid culture method; the phage-infected bacteria were plated on agar containing varying concentrations of streptomycin and their survival curves were compared with those of the control. As shown in Table 4, transduction of two-step resistance into one-step resistant cells did occur. This second-step resistance, however, might have been brought about by the mutation at the indifference locus, because negative results were obtained with several other two-step resistant strains as donors.

Transduction of first-step resistance into another one-step resistant strain

Transduction of first step into another type of one-step resistant mutant was undertaken with the liquid culture method. The results again failed to show significant differences from the control experiments. As will be reported in a following paper, genetically multiple types of one-step intermediate 
resistance were found by looking for wild-type, sensitive and fast-growing transductants instead of looking for resistant transductants.

Transduction of indifference into one-step intermediate resistant bacteria

A one-step mutant which is resistant to $50 \mu \mathrm{g}$. streptomycin $/ \mathrm{ml}$. was infected with phage from an indifferent mutant and the infected bacteria were aerated at $37^{\circ}$ for $10 \mathrm{hr}$. The transductants were then detected by plating aliquots on agar medium containing $1000 \mu \mathrm{g}$. streptomycin $/ \mathrm{ml}$. The frequency of transductants per total viable bacteria was $1 / 4.5 \times 10^{5}$ which is similar to those obtained with wild-type recipient. The indifferent transductants obtained with the one-step resistant mutant as a recipient were found to be all slow growers, even when replicated on to streptomycin-free agar medium.

Table 4. Transduction of second step resistance into one-step intermediate resistant bacteria in Salmonella typhimurium strain LT-2 using the one-step mutant (resistant to $100 \mu \mathrm{g} . / \mathrm{ml}$.) as a recipient and the two-step intermediate-resistant mutant (resistant to $1000 \mu \mathrm{g} . / \mathrm{ml}$.) as a donor

\section{Experiment 1}

\begin{tabular}{|c|c|c|c|c|c|}
\hline \multirow[b]{2}{*}{ Donor } & \multirow{2}{*}{$\begin{array}{l}\text { Concentration } \\
\text { of streptomycin } \\
\text { in agar plate } \\
(\mu \mathrm{g} . / \mathrm{ml} .)\end{array}$} & \multicolumn{4}{|c|}{$\begin{array}{l}\text { No. of colonies formed on streptomye } \\
\text { agar plates when phage-infected cultur } \\
\text { were aerated for the following number } \\
\text { hr. before plating }\end{array}$} \\
\hline & & 1 & 3 & 5 & 23 \\
\hline No phage & 500 & 19 & 20 & 45 & $\mathbf{5 2}$ \\
\hline & 1000 & 9 & 7 & 14 & 22 \\
\hline Phage from one-step mutant & 500 & 6 & 7 & 10 & 14 \\
\hline resistant to $100 \mu \mathrm{g} . / \mathrm{ml}$ & 1000 & 2 & 1 & 5 & 11 \\
\hline Phage from two-step mutant & $\mathbf{5 0 0}$ & 3 & 4 & 10 & 1085 \\
\hline resistant to $1000 \mu \mathrm{g} . / \mathrm{ml}$. & 1000 & 1 & 2 & 4 & 429 \\
\hline
\end{tabular}

Experiment 2

\begin{tabular}{|c|c|c|c|c|}
\hline \multirow{2}{*}{$\begin{array}{l}\text { Concentration } \\
\text { of streptomycin } \\
\text { in agar plate } \\
(\mu \mathrm{g} . / \mathrm{ml} .)\end{array}$} & \multicolumn{4}{|c|}{$\begin{array}{c}\text { No. of colonies formed on streptomyci } \\
\text { agar plates when phage-infected cultur } \\
\text { were aerated for the following number } \\
\text { hr. before plating }\end{array}$} \\
\hline & 3 & 6 & $10 \cdot 5$ & 23 \\
\hline 500 & 13 & 30 & 17 & 16 \\
\hline 1000 & 4 & 11 & 12 & 5 \\
\hline 2500 & - & - & - & o \\
\hline 500 & 2 & 4 & 4 & 21 \\
\hline 1000 & 0 & 1 & 1 & 12 \\
\hline 2500 & - & - & - & 1 \\
\hline 500 & 2 & 5 & 156 & 452 \\
\hline 1000 & 1 & 1 & 73 & 265 \\
\hline 2500 & - & - & - & 8 \\
\hline
\end{tabular}

The mixture of the equal volumes of recipient bacteria $\left(1 \cdot 2 \times 10^{9} / \mathrm{ml}\right.$., grown on agar plates and suspended in liquid medium to avoid large colonies) and donor phage $\left(10^{10} / \mathrm{ml}\right.$.) was aerated at $37^{\circ}$ and, at various times, $0.1 \mathrm{ml}$. of the undiluted culture was plated on streptomycin agar. To the control culture equal volume of liquid medium was added instead of phage. All the plates were incubated for 5 days before the colonies were scored. 


\section{DISCUSSION}

From what has been described above, it is obvious that the first report on transduction of streptomycin resistance by Zinder \& Lederberg (1952) is quite reproducible when the streptomycin indifferent mutant is used as a donor and sufficient divisions are allowed for the infected bacteria to express their phenotype. The failure of some previous workers to transduce streptomycin resistance is assumed to be due to one of two reasons. Either they may have used intermediate resistant mutants as donors in which transduction is very difficult to achieve or they may not have allowed enough divisions of the infected bacteria before they were exposed to streptomycin.

The nature of the delayed expression of indifferent phenotype in its transduction has not yet been fully analysed but, from the work of Lederberg (1951), it is very likely that this delay involves a segregation lag because of the possible recessiveness of the indifference locus to its wild-type allele. If this is the case, the absence of abortive transduction is also understandable, because the cells which contain both indifferent and sensitive allelic genes should be phenotypically sensitive to streptomycin and, if they are exposed to streptomycin before the sensitive allele is segregated out by bacterial division, they should be killed by the antibiotic. Therefore, such abortive transductions as reported by Lederberg (1956), Stocker (1956) and Ozeki (1956) should not be expected to happen in this case.

Segregation lag may be a major factor of the delay, but the fact that streptomycin resistance is gradually expressed from partial to complete resistance seems to suggest the participation of phenomic lag in this delay. Unfortunately the biochemical mechanism of streptomycin action and resistance is almost unknown, although it has been investigated by Umbreit, Smith \& Oginsky (1951).

One-step resistance, which is probably indifference in most cases, is the most extensively used marker in transformation experiments with Diplococcus pneumoniae and Haemophilus influenzae. Recently Corey \& Starr (1957) have reported on the transformation of streptomycin ressistance in Xanthomonas phaseoli. When we investigate the behaviour of the streptomycin resistance locus reported in these papers, we find a contradiction, i.e. in D. pneumoniae (Hotchkiss, 1957) this locus seems to behave as a dominant gene, whereas in $H$. influenzae (Alexander \& Leidy, 1953) and $X$. phaseoli (Corey \& Starr, 1957) it seems to be a recessive gene. In Escherichia coli it is definitely a recessive gene from the work of Lederberg (1951) and in Salmonella typhimurium it is very likely to be recessive from what has been reported in the present paper. It is interesting to find that a supposedly equivalent factor behaves as dominant in some species, while it acts as recessive in others; but this would be expected if one were a case of a suppressor gene.

Streptomycin indifference can be transduced not only into wild-type but also into one-step intermediate resistant bacteria. The fact that the indifferent transductants, developed from one-step intermediate resistant bacteria, are all slow growers seems to suggest that the transductants have both the one-step resistance locus and the indifference locus, and that the one-step intermediate 
resistance locus is epistatic to the indifference locus in controlling the slow growth, while in the control of complete streptomycin resistance the indifference locus is epistatic to the intermediate resistance locus.

In the various aspects of transduction of indifference that were also studied, this marker was found to behave in quite similar ways to other chromosomal markers.

In contrast to transduction of indifference, intermediate resistance seems to be difficult to transduce into sensitive bacteria. In many experiments there seemed to be slight increases in the numbers of the colonies developed on streptomycin plates seeded with sensitive bacteria infected with phage from a resistant mutant over those of the control experiments in which either the phage from wild-type bacteria or no phage was added to the recipient bacteria. Sometimes, on the other hand, there were no differences found.

However, the transduction of a second step into one-step resistant cells did occur successfully. The long delay before the resistant transductants were detected possibly indicates that multiple-step streptomycin resistance is recessive as is streptomycin indifference. In this transduction experiment, however, the second step mutation might have been brought about by the mutation at the indifference locus. Furthermore, in none of the tested combinations of one-step resistant mutants as recipients and donors, did a significant transduction to higher resistance occur.

One may argue that intermediate resistance might be inherited by cytoplasmic factors, but the spontaneous development of fast-growing mutants with lower levels of resistance and the consistent and reproducible transduction of wild-type alleles into the resistance loci which will be reported in a following paper seem to make this assumption unlikely. For a conclusive proof of the chromosomal nature of the control of resistance, the discovery of linkage of resistance loci to other chromosomal markers is felt necessary. Studies along this line are now in progress, but so far no linkage relationship has been found. The failure to obtain two-step resistant transductants by crossing one-step resistant mutants with other types of one-step resistant mutants may indicate that the loci which control first-step resistance are different in action from those which control second steps.

The reason why one-step resistance is not easily transduced into sensitive bacteria is not clear as yet; it is assumed that transduction of resistance does take place, but that the resistant transductants are possibly selected against by the sensitive-non-transductants due to differences in their growth rates. It was shown that the difficulty of detecting resistant transductants is not due to 'co-killing' and the failure even with a streptomycin-sensitive slow-growing recipient suggests a need for improving the technique.

Before the transduction of resistance becomes reproducible with some technical improvement, it may be premature to discuss the failure to obtain two-step resistant transductants by crossing two one-step resistant mutants by transduction. At least at the present time it is not possible to analyse the genetics of intermediate resistance by crossing one-step resistants and looking for higher resistance. 
We are very grateful to Dr Francis J. Ryan for generously giving us a chance of working in his laboratory, for valuable suggestions and discussions in conducting this work and also for much help in writing the manuscript. Our thanks are also due to Dr M. Demerec for kindly supplying his strains.

This work was supported in part by research grants from the U.S. Public Health Service, the National Science Foundation and the American Cancer Society.

\section{REFERENCES}

ADams, M. H. (1950). Methods of study of bacterial viruses. Meth. med. Res. $2,1$.

AlexANDER, H. E. \& LEIDY, G. (1953). Induction of streptomycin resistance in sensitive Hemophilus influenzae by extracts containing desoxyribonucleic acid from resistant Hemophilus influenzae. J. exp. Med. 97, 17.

Baron, L. S. (1953). Genetic transfers by means of Vi phage lysates. Cold Spr. Harb. Symp. quant. Biol. 18, 271.

Bryson, V. \& Demerec, M. (1955). Bacterial resistance. Amer. J. Med. 18, 1723.

Bryson, V. \& Szybalski, W. (1955). Microbial drug resistance. Advanc. Genet. 7, 1.

Cavaldi, L. L. (1952). Genetic analysis of drug resistance. Bull. Wld Hlth Org. 6, 185.

Corey, R. R. \& Stark, M. P. (1957). Genetic transformation of streptomycin resistance in Xanthomonas phaseoli. J. Bact. 74, 146.

Demerec, M. (1950). Reaction of populations of uninuclear organisms to extreme changes in environment. Amer. Nat. 84, 5.

Hotchkiss, R. D. (1951). Transfer of penicillin resistance in pneumococci by the desoxyribonucleate derived from resistant cultures. Cold Spr. Harb. Symp. quant. Biol. 16, 457.

Нотснкіss, R. D. (1952). The biological nature of the bacterial transforming factors. Exp. Cell Res. Suppl. 2, 383.

Hotchkiss, R. D. (1957). Criteria for quantitative genetic transformation of bacteria. A Symposium on the Chemical Basis of Heredity, p. 321. Baltimore: The Johns Hopkins Press.

Hurwitz, C. \& Rosanao, C. L. (1958). Studies on mechanism of the streptomycin reaction. I. Phosphate reversal of the dihydrosteptomycin inactivation of Escherichia coli. J. Bact. 75, 11.

Isekr, S. \& SakaI, T. (1954). Transduction of biochemical properties in Salmonella $\mathrm{E}$ group. Proc. Jap. Acad. 30, 143.

LEDERBERG, J. (1951). Streptomycin resistance: a genetically recessive mutation. J. Bact. 75, 11.

LEDERBERG, J. (1956). Linear inheritance in transductional clones. Genetics, 41, 845.

Lederberg, J. \& Lederberg, E. M. (1952). Replica plating and indirect selection of bacterial mutants. J. Bact. $63,399$.

LENNOx, E. S. (1955). Transduction of linked genetic characters of the host by bacteriophage P1. Virology, 1, 190.

Newcombe, H. B. (1952). A comparison of spontaneous and induced mutations of Escherichia coli to streptomycin resistance and dependence. J. cell. comp. Physiol. 39, Suppl. 1, 13.

Newcombe, H. B. \& Nyноцm, M. H. (1950). The inheritance of streptomycin resistance and dependence in crosses of $E$. coli. Genetics, 35, 603.

OzEkr, H. (1956). Abortive transduction in purine-requiring mutants of Salmonella typhimurium. Genetic studies with bacteria. Publ. Carneg. Inst. 612, 97.

SAz, A. K. \& Eagle, H. (1953). The co-killing of penicillin sensitive and penicillin resistant bacteria at low concentrations of the antibiotic. J. Bact. 66, 347.

ShImizu, E. (1955). Transduction of biological properties in Salmonella typhimurium. Gumma J. Med. Sci. 4, 19. 
Stocker, B. A. D. (1956). Abortive transduction of motility in salmonella; a nonreplicated gene transmitted through many generations to a single descendent. J. gen. Microbiol. 15, 575 .

Umbreit, W. W., Smith, P. H. \& OGinsky, E. L. (1951). The action of streptomycin. V. The formation of citrate. J. Bact. 61, 595.

Watanabe, T. (1954). Genetic studies on the mechanism of acquired streptomycinresistance in microorganisms. Keio J. Med. 3, 193.

Watanabe, T., Fukasawa, T. \& Ushiba, D. (1957). Probable absence of direct induction of bacterial resistance to streptomycin. J. Bact. 73, $\mathbf{7 7 0}$.

Zinder, N. D. (1955). Bacterial transduction. J. cell. comp. Physiol. 45, Suppl. $2,23$.

ZiNDER, N. D. \& LeDerberg, J. (1952). Genetic exchange in salmonella. J. Bact. 64,679 .

(Received 18 July 1958) 